\title{
Role Perception of Farm Facilitators under Bhoochetana Programme of KSDA in Chickballapur District of Karnataka, India
}

\author{
Tanweer Ahmed ${ }^{*}$, B.K. Narayana Swamy ${ }^{1}$ and N. Rajanna ${ }^{2}$ \\ ${ }^{1}$ Department of Agricultural Extension, GKVK, UAS, Bengaluru - 560065, Karnataka, India \\ ${ }^{2}$ ATIC, GKVK, Bengaluru, Karnataka, India \\ *Corresponding author
}

\section{Keywords}

Bhoochetana. Role perception, ICRISAT, Farm facilitators

\section{Article Info}

Accepted:

26 December 2017

Available Online:

10 January 2018

A B S T R A C T

The present investigation was carried out in Chickballapur district covering six taluks viz., Bagepalli, Chickballapur, Chintamani, Gudibande Gowribidanur and Siddlaghatta to assess the role perception of farm facilitators under Bhoochetana Programme. A total number of 90 farm facilitators were interviewed for the purpose. The results revealed that about 42.00 per cent of farm facilitators belonged to average role perception category followed by 31.00 per cent belonged to better role perception category and 27.00 per cent of farm facilitators belonged to poor role perception category. Among the different facilitation roles, the facilitation role that was perceived better by the farm facilitators was organizing village level meetings and training programmes under the guidance of KSDA/ ICRISAT scientists, while poorly perceived facilitation as role in water, soil and nutrient management. The five best perceived items of the facilitation roles as indicated by the overall rank were (i) To provide information about improved varieties, seed treatment, composting etc, (ii) Motivating the farmers to attend programme/ training on particular crop, organized by Karnataka State Department of Agriculture (KSDA)/ ICRISAT, (iii) Providing information about improved agricultural practices, (iv) Arranging the field days and field visits under the guidance of KSDA/ ICRISAT Scientists, (v) Helping the farmers in getting the fertilizers and soil amendments from Raita Samparka Kendra. The five least perceived items by the farm facilitators happened to be (i) To provide information on INM, (ii) To send report of soil testing to claim financial assistance from RSK, (iii) To provide information on water conservation practices, (iv) Recording the problems encountered in identified village, (v) To conduct demonstrations on importance of micronutrients and their effect on yield differentiation.

\section{Introduction}

Rainfed agriculture is practiced on $80.00 \%$ of the world's farm area, and generates almost $60 \%$ of the world's staple foods. It accounts for the livelihoods of 80.00 per cent of the world's population. In India, it is practiced on 85 million hectares and produces $44.00 \%$ of food and fodder. Hence, rainfed farming plays a key role in the economic development of the country. Karnataka has the biggest area under rainfed agriculture in India after Rajasthan. Crop yields in the rainfed areas are 1-1.5 tonnes per hectare, which are two to five times less than those on research farms. Only 35 to 45.00 per cent of rainwater is presently used to 
grow dry land crops in the state. Hence, there is huge scope for improving rainwater harvesting and its efficient use for crop production. Advances in soil and water management technologies including better cultivars could unlock the vast potential of rainfed agriculture. Hence Government of Karnataka has initiated a novel project Bhoochetana to increase average productivity of selected rainfed crops by $20.00 \%$. At the field level for effective transfer of technology and to achieve the objectives of Bhoochetana programme farm facilitators are appointed on contract basis, who have minimum S.S.L.C qualification. These farm facilitators serve as linking agents between the farmer and the Karnataka State Department of Agriculture (KSDA), Agricultural universities and ICRISAT. In this background, the present study was taken up with the specific objective i.e., to measure the role perception of farm facilitators in Bhoochetana Programme.

\section{Materials and Methods}

The present study was conducted in Chickballapur district of Karnataka state during the year 2014-15. All the six taluks viz., Bagepalli, Chickballapur, Chintamani, Gudibande Gowribidanur and Siddlaghatta were covered. From each taluk 15 farm facilitators were randomly selected making a total sample size of 90. Data were collected using a pre tested structured interview schedule.

Data were analyzed using appropriate statistical tools like frequency, percentage, mean, standard deviation etc. The Ex Post Facto research design used for the study. Role perception of farm facilitators was measured making use of specially developed instrument and was Likert type scale. For the purpose of developing role perception instrument, the roles of the farm facilitators assigned in the Bhoochetana programme through Government of Karnataka were studied in detail. The roles of farm facilitators were stated specifically on a perception instrument within the framework of specified roles under Bhoochetana programme. Based on roles, various role items statements were stated specifically and grouped into six areas namely (i) Being link worker between farmers and extension staff, (ii) Planning and compilation of information of local resources, (iii) Organizing village level meetings and training programmes under guidance of KSDA/ ICRISAT Scientists, (iv) Role in water, soil and nutrient management, (v) Role in farmers field school, (vi) Maintenance and submitting the progress report. Five items were included under each role areas.

Totally, there were 30 items in the instrument describing the various aspects of the roles of farm facilitators in Bhoochetana programme The responses were collected on five point continuum namely 'Very important', 'important', 'less important', 'least important', and 'not important' by assigning scores 4,3 , 2,1 , and 0 , respectively on each role items. The score for each item under different role areas were added to obtain the total score of the respondents. Thus, the minimum and maximum possible scores were 0 and 120 , respectively. Based on mean score obtained by the respondents they were categorized into three groups as under.

\begin{tabular}{|l|c|}
\multicolumn{1}{c|}{ Category } & Criteria \\
\hline Poor & $<($ Mean $-1 / 2 \mathrm{SD})$ \\
\hline Average & Between $($ Mean $\pm 1 / 2 \mathrm{SD})$ \\
\hline Better & $>($ Mean $+1 / 2 \mathrm{SD})$ \\
\hline
\end{tabular}

Further, a detailed analysis of the role perception on each item was carried out by calculating the mean score for each role item. Thus, the minimum and maximum possible scores on each item were 0 and 5 , respectively. 


\section{Results and Discussion}

\section{Overall role perception of farm facilitators in Bhoochetana Programme}

The findings related to the overall role perception of farm facilitators are presented in Table 1. It could be observed that 42.00 per cent of farm facilitators belonged to average role perception category followed by 31.00 per cent belonged to better role perception category and 27.00 per cent of farm facilitators belonged to poor role perception category. In gist 73.00 per cent of respondents were found to have average to better perception towards Bhoochetana programme. The probable reason for the above trend of findings might be due to education level of farm facilitators and orientation given to them in the training by the training institutes related to Bhoochetana programme. The job chart provided to them and their frequent exposure to trainings given to them might have helped to develop the close association with Agriculture officer and Assistant Agriculture officer in Raita Samparka Kendra after the training and an insight of field problems might have influenced this trend of findings.

\section{Role perception of farm facilitators in different facilitation roles}

A detailed analysis of role perception of farm facilitators in respect of six roles viz., being link worker between farmers and extension staff, planning and compilation of information of local resources, organizing village level meetings and training programmes under the guidance of KSDA/ ICRISAT Scientists, role in water, soil and nutrient management, role in farmers field school, and maintenance and submitting the progress report is presented in Table 2. A cursory look at this table indicated that the mean score were highest under the facilitation role organizing village level meetings and training programmes under the guidance of KSDA/ ICRISAT Scientists (16.83), followed by role in farmers field school (16.40), being link worker between farmers and extension staff (15.93), maintenance and submitting the progress report (15.43), planning and compilation of information of local resources (15.13) and lastly role in water, soil and nutrient management (13.75).

Item wise role perception of farm facilitators

Table 3 summarizes the extent to which the different items of facilitation roles were perceived by the farm facilitators. The five best perceived items of the facilitation roles as indicated by the overall rank were (i) To provide information about improved varieties, seed treatment, composting etc ( $1^{\text {st }}$ rank), (ii) Motivating the farmers to attend programme/ training on particular crop, organized by KSDA/ ICRISAT ( $2^{\text {nd }}$ rank), (iii) Providing information about improved agricultural practices $\left(3^{\text {rd }}\right.$ rank), (iv) Arranging the field days and field visits under the guidance of KSDA/ ICRISAT Scientists (4 ${ }^{\text {th }}$ rank), (v) Helping the farmers in getting the fertilizers and soil amendments from Raita Samparka Kendra $\left(5^{\text {th }}\right.$ rank). Incidentally the first, second and third items belonged to facilitation role of organizing village level meetings and training programmes under the guidance of KSDA/ ICRISAT Scientists. Fourth item belonged to facilitation role in farmers' field school and fifth item belonged to the facilitation role of being link worker between farmers and extension staff.

The five least perceived items by the farm facilitators happened to be (i) To provide information on INM ( $30^{\text {th }}$ rank), (ii) To send report of soil testing to claim financial assistance from RSK (29 ${ }^{\text {th }}$ rank), (iii) To provide information on water conservation practices ( $28^{\text {th }}$ rank), (iv) Recording the problems encountered in identified village 
( $27^{\text {th }}$ rank), (v) To conduct demonstrations on importance of micronutrients and their effect on yield differentiation $\left(26^{\text {th }}\right.$ rank). Among the least perceived items of facilitation roles, first, second, third and fifth items were related to the facilitation role in water, soil and nutrient management. Fourth item was related to facilitation role of maintaining and submitting the progress report.

Table.1 Overall role perception of farm facilitators in Bhoochetana programme

\begin{tabular}{|c|c|c|c|c|c|c|}
\hline \multirow{2}{*}{ SI. No. } & Role perception & Criteria & Farm facilitators & Mean & SD \\
\cline { 1 - 5 } & & & No. & $\%$ & & \\
\hline $\mathbf{1}$ & Poor & Upto 86.95 & 24 & 27.00 & 93.48 & 13.06 \\
\hline $\mathbf{2}$ & Average & $>86.95$ upto 100 & 38 & 42.00 & & \\
\hline $\mathbf{3}$ & Better & $>100$ & 28 & 31.00 & & \\
\hline
\end{tabular}

Table.2 Role perception of farm facilitators in different facilitation roles

\begin{tabular}{|c|c|c|c|c|}
\hline & & & \multicolumn{2}{|c|}{$(\mathrm{n}=90)$} \\
\hline $\begin{array}{l}\text { Sl. } \\
\text { No. }\end{array}$ & Facilitation Roles & $\begin{array}{l}\text { Number of } \\
\text { items }\end{array}$ & Mean & SD \\
\hline 1 & Being link worker between farmers and extension staff & 5 & 15.93 & 2.14 \\
\hline 2 & Planning and compilation of information of local resources. & 5 & 15.13 & 2.89 \\
\hline 3 & $\begin{array}{l}\text { Organizing village level meetings and training programmes } \\
\text { under the guidance of KSDA/ ICRISAT Scientists. }\end{array}$ & 5 & 16.83 & 2.18 \\
\hline 4 & Role in water, soil and nutrient management & 5 & 13.75 & 3.02 \\
\hline 5 & Role in farmer field school & 5 & 16.40 & 2.84 \\
\hline 6 & Maintenance and submitting the progress report & 5 & 15.43 & 3.22 \\
\hline
\end{tabular}

Table.3 Item wise Role perception of farm facilitators

\begin{tabular}{|c|c|c|c|c|}
\hline & & & & 90) \\
\hline $\begin{array}{l}\text { Sl. } \\
\text { No. }\end{array}$ & Items of Facilitation Roles & $\begin{array}{l}\text { Mean } \\
\text { Score }\end{array}$ & $\begin{array}{l}\text { Rank under } \\
\text { each role }\end{array}$ & $\begin{array}{l}\text { Overall } \\
\text { Rank }\end{array}$ \\
\hline I Bei & ng link worker between Farmers and Extension staff & & & \\
\hline 1 & $\begin{array}{l}\text { Helping in dissemination of technologies with the assistance } \\
\text { of AAO. }\end{array}$ & 3.23 & 2 & 9 \\
\hline 2 & $\begin{array}{l}\text { Helping the farmers in getting good seeds from Raita } \\
\text { samparka Kendra. }\end{array}$ & 3.11 & 4 & 18 \\
\hline 3 & $\begin{array}{l}\text { Helping the farmer in getting the fertilizers and soil } \\
\text { amendments from Raita Samparka Kendra. }\end{array}$ & 3.34 & 1 & 5 \\
\hline 4 & $\begin{array}{l}\text { Help in providing information about farmers problems to } \\
\text { higher authorities. }\end{array}$ & 3.01 & 5 & 23 \\
\hline 5 & Helping/ assisting in conducting primary survey & 3.23 & 2 & 9 \\
\hline II $\mathbf{P}$ & anning and compilation of information of local resources & & & \\
\hline 6 & Collecting the information in identified village. & 2.97 & 5 & 25 \\
\hline 7 & Collecting the information about fertility of land. & 3.05 & 1 & 19 \\
\hline 8 & Collecting the information about irrigation sources. & 3.00 & 4 & 24 \\
\hline
\end{tabular}




\begin{tabular}{|c|c|c|c|c|}
\hline 9 & $\begin{array}{l}\text { Assisting AAO in planning of programmes based on farm } \\
\text { population. }\end{array}$ & 3.05 & 1 & 19 \\
\hline 10 & $\begin{array}{l}\text { Collecting information about farmer's previous year crop } \\
\text { yield, fertilizer application and usage of seeds. }\end{array}$ & 3.04 & 3 & 22 \\
\hline \multicolumn{5}{|c|}{$\begin{array}{l}\text { III Organizing villaş } \\
\text { ICRISAT Scientists }\end{array}$} \\
\hline 11 & $\begin{array}{l}\text { Selecting the model village under guidance of Assistant } \\
\text { Agriculture Officer. }\end{array}$ & 3.16 & 5 & 14 \\
\hline 12 & $\begin{array}{l}\text { Organizing the village meeting and selection of interested } \\
\text { farmers. }\end{array}$ & 3.26 & 4 & 8 \\
\hline 13 & $\begin{array}{l}\text { Motivating the farmers to attend programme/ training on } \\
\text { particular crop/ subject organized by KSDA/ ICRISAT. }\end{array}$ & 3.44 & 2 & 2 \\
\hline 14 & Providing information about improved agricultural practices. & 3.38 & 3 & 3 \\
\hline 15 & $\begin{array}{l}\text { To provide information about improved varieties, seed } \\
\text { treatment, composting etc }\end{array}$ & 3.56 & 1 & 1 \\
\hline \multicolumn{5}{|c|}{ IV Role in water, soil and nutrient management } \\
\hline 16 & $\begin{array}{l}\text { Collecting and sending the soil sample for soil testing } \\
\text { laboratories for soil testing. }\end{array}$ & 3.14 & 1 & 17 \\
\hline 17 & $\begin{array}{l}\text { To send report of soil testing to claim financial assistance } \\
\text { from RSK. }\end{array}$ & 2.77 & 4 & 29 \\
\hline 18 & To provide information on INM. & 2.05 & 5 & 30 \\
\hline 19 & To provide information on water conservation practices. & 2.82 & 3 & 28 \\
\hline 20 & $\begin{array}{l}\text { To conduct demonstrations on importance of micronutrients } \\
\text { and their effect on yield differentiation. }\end{array}$ & 2.95 & 2 & 26 \\
\hline \multicolumn{5}{|c|}{ V Role in farmers field school } \\
\hline 21 & Identification and selection of farmer leader. & 3.17 & 5 & 13 \\
\hline 22 & $\begin{array}{l}\text { Conducting FFS in donor farmers field with providing all } \\
\text { logistics of FFS. }\end{array}$ & 3.23 & 4 & 9 \\
\hline 23 & $\begin{array}{l}\text { To conduct discussion with selected members in each } \\
\text { meetings. }\end{array}$ & 3.27 & 3 & 7 \\
\hline 24 & $\begin{array}{l}\text { Provide information based on Package of Practice to the } \\
\text { farmers through literature. }\end{array}$ & 3.33 & 2 & 6 \\
\hline 25 & $\begin{array}{l}\text { Arranging the Field days and field visits under the guidance } \\
\text { of Department officers/ ICRISAT Scientists }\end{array}$ & 3.37 & 1 & 4 \\
\hline \multicolumn{5}{|c|}{ VI Maintenance and submitting the progress report } \\
\hline 26 & Maintaining the records of farmers participated in FFS. & 3.15 & 2 & 15 \\
\hline 27 & Recording the problems encountered in identified village. & 2.83 & 5 & 27 \\
\hline 28 & $\begin{array}{l}\text { Maintenance of records for recording the observation of trails } \\
\text { and demonstrations conducted. }\end{array}$ & 3.05 & 4 & 19 \\
\hline 29 & Arranging for the visits of Department of Agriculture & 3.15 & 2 & 15 \\
\hline 30 & Submitting the reports to officers of RSK. & 3.23 & 1 & 9 \\
\hline
\end{tabular}


The best perceived role item in the facilitation role of being link worker between farmers and extension staff was, helping the farmer in getting the fertilizers and soil amendments from Raita Samparka Kendra, while the least perceived item was, help in providing information about farmers problems to higher authorities. In the facilitation role of planning and compilation of information of local resources, the best perceived role was collecting the information about fertility of land, while the least perceived item was collecting the information in identified village. In facilitation role of organizing village level meetings and training programmes under the guidance of KSDA/ ICRISAT scientists, the best perceived role was to provide information about improved varieties, seed treatment, composting etc. while the least perceived item was selecting the model village under guidance of Assistant Agriculture Officer. In facilitation role of role in water, soil and nutrient management, the best perceived item was collecting and sending the soil sample for soil testing laboratories for soil testing while the least being to provide information on INM. In facilitation role of role in farmers' field school, the best perceived item was arranging the field days and field visits under the guidance of KSDA/ ICRISAT scientists, while, the least perceived item was identification and selection of farmer leader. In facilitation role of maintenance and submitting the progress report, the best perceived item was submitting the reports to officers of RSK, while the least perceived item being recording the problems encountered in identified village.

It can be concluded from the above findings that role perception was better in the facilitation role of organizing village level meetings and training programmes under the guidance of KSDA/ ICRISAT Scientists and poor in water, soil and nutrient management.
Hence the concerned scientists and extension personnel should focus on imparting the adequate trainings to the farm facilitators regarding water, soil and nutrient management practices like method of soil sampling, water sampling, importance of micro nutrients, integrated nutrient management etc.

\section{References}

Bhoochetana, 2009. Boosting Rainfed Agriculture in Karnataka, Karnataka State Department of Agriculture.

Deepak, M.P., 2003. A Study on Perception of Beneficiaries and Non-Beneficiaries towards WYTEP Programme in Dharwad. M.Sc. (Agri.) Thesis (Unpub.), Univ. Agric. Sci., Dharwad.

Deshmukh, B.A., Swathi, D.S. And Patil, S.S., 2010. Perception of Rural Youth about Adarsh Gaon Yojana. J. Rural Dev., 29(1): 35-41.

Eswarappa, G., Goudar, G.B. And Basavaraddi, M., 1999. Role Perception and Role Performance of Link Workers under Women Youth Training Extension Project. Maharashtra J. Extn.Edu., 18: 23-26.

Goudar, G.B., 1997. A Study on Role Perception and Role Performance of Link Workers under WYTEP Programme. M. Sc. (Agri.) Thesis (Unpub.), Univ. Agric. Sci., Bangalore.

Khare, R.Y., Khare, K.N. and Dubey, K.M., 1998. Role Perception of Village Panchayat Chairman towards Agricultural Development. Maharashtra J. Extn.Edu., 16:323-325.

Sandic, A. L., 2006. A Study on Organizational Climate Perception by Veterinary Officers and Veterinary Livestock Inspectors of Department of Animal Husbandry and Veterinary Service in Karnataka. M. Sc. (Agri.) 
Thesis (Unpub.), Univ. Agric. Sci., Dharwad.

Siddaramaiah, B.S., and Shivalingegowda, N.S., 1987. Job perception, job performance and job satisfaction of extension guides in the University extension system of Karnataka. Indian Journal of Extension Education, 23(1\&2): 48-50.
Sontakki, B.S., 1995. A study on organizational climate perception and related factors of taluk level extension personnel (ADF-IIs) of KSDF. Ph. D. Thesis, Univ. Agric. Sci., Dharwad.

Wattamwar, T. V. and Deshmukh, A. K., 1997. Role perception of contact farmers in $\mathrm{T}$ and $\mathrm{V}$ system. Maharashtra J. Extn.Edu., 16: 354-355.

\section{How to cite this article:}

Tanweer Ahmed, B.K. Narayana Swamy and Rajanna, N. 2018. Role Perception of Farm Facilitators under Bhoochetana Programme of KSDA in Chickballapur District of Karnataka, India. Int.J.Curr.Microbiol.App.Sci. 7(01): 3459-3465. doi: https://doi.org/10.20546/ijcmas.2018.701.407 